\title{
Utilization of Neem Leaf Extract on Biosynthesis of Iron Oxide Nanoparticles
}

\author{
Nur Diyana Syazwani Zambri ${ }^{1}$, Nurul Izza Taib ${ }^{2, *}$, Famiza Abdul Latif ${ }^{1}$ and Zakiah Mohamed ${ }^{1}$ \\ 1 Faculty of Applied Sciences, Universiti Teknologi MARA, UiTM, Shah Alam 40450, Selangor, Malaysia; \\ ndiyana1811@gmail.com (N.D.S.Z.); famiza@uitm.edu.my (F.A.L.); zakiah626@uitm.edu.my (Z.M.) \\ 2 Faculty of Applied Sciences, Universiti Teknologi MARA, Perak Branch, Tapah Campus, \\ Tapah Road 35400, Perak, Malaysia \\ * Correspondence: izza257@uitm.edu.my; Tel.: +601-8392-0120
}

Received: 9 July 2019; Accepted: 24 September 2019; Published: 22 October 2019

check for updates

\begin{abstract}
The present work reports the successful synthesis of biosynthesized iron oxide nanoparticles $\left(\mathrm{Fe}_{3} \mathrm{O}_{4}\right.$-NPs) with the use of non-toxic leaf extract of Neem (Azadirachta indica) as a reducing and stabilizing agent. The successful synthesis was confirmed by infrared spectra analysis with strong peak observed between $400-600 \mathrm{~cm}^{-1}$ that corresponds to magnetite nanoparticles characteristics. $\mathrm{X}$-ray diffraction (XRD) analysis revealed that iron oxide nanoparticles were of high purity with crystalline cubic structure phases in nature. Besides, the average size of magnetite nanoparticles was observed to be 9-12 nm with mostly irregular shapes using a transmission electron microscope (TEM) and was supported by field emission scanning electron microscope (FESEM). Energy dispersive X-ray analysis shown that the elements iron $(\mathrm{Fe})$ and oxygen $(\mathrm{O})$ were present with atomic percentages of $33.29 \%$ and $66.71 \%$, respectively. From the vibrating sample magnetometer (VSM) analysis it was proven that the nanoparticles exhibited superparamagnetic properties with a magnetization value of $73 \mathrm{emu} / \mathrm{g}$ and the results showed superparamagnetic behavior at room temperature, suggesting potential applications for a magnetic targeting drug delivery system.
\end{abstract}

Keywords: biosynthesis; iron oxide nanoparticles; Azadirachta indica; superparamagnetic

\section{Introduction}

The emergence of nanoscale iron oxide nanoparticles with exceptional properties such as biocompatibility, stability in physiological environments, and size-dependent magnetic properties, superparamagnetism, high coercivity, high saturation magnetization and low toxicity [1,2], opens up a new window for medicine, biosensors, and drug delivery fields [2-14]. They are the only type of magnetic nanoparticles that are approved by food and drug administration (FDA) for clinical use [15]. Iron oxide nanoparticles have been realized by different synthesis routes through physical and chemical methods, which includes co-precipitation methods [16], micro-emulsion methods [17,18], sol-gel methods [19], solvothermal methods [20], thermal decomposition methods [21-24] and hydrothermal methods [25].

However, the chemical synthesis of iron oxide nanoparticles has drawbacks such as the usage of hazardous chemicals, formation of hazardous byproducts, contamination from precursor chemicals [26], highly reactive in nature and tend to form aggregates resulting in loss of reactivity $[27,28]$, and the resulting iron oxide nanoparticles have limited application in biological systems due to low biocompatibility [29]. In addition, common methods like thermal decomposition and hydrothermal methods used to synthesize iron oxide nanoparticles also required high temperatures, high pressure, large amounts of toxic and expensive organic solvents [3]. 
Therefore, there is a growing need to develop clean, nontoxic, and environmentally friendly procedures for nanoparticle synthesis. Due to current sustainability concerns, the exploration of eco-friendly and green synthesis for the production of nanoparticles based on plant extracts has earned significant attention. Green synthesis are gaining importance by virtue of: (1) Clean and eco-friendly methods, as water is an environmentally friendly solvent [30]; (2) it is able to scale up [31]; (3) high energy and high pressure are not required, causing significant energy saving [32] and (4) finally, overall synthesis process is cost-effective as the active biological component able to act as a reducing and capping agent [30].

Great advances have been made for nanoparticle synthesis using a very wide range of biological resources like microorganisms and plants [33]. Plant extracts able to reduce the metal ions in a shorter time whereas microorganism-based methods require a longer time. The easy availability of plants in nature, make them more preferred biological resources than microbes [34-37]. Meanwhile, for microorganism-mediated nanoparticles, synthesis involves a lengthy process in maintaining cultures, the obligatory constraint of aseptic conditions, which requires trained staff, and these raise the scaling-up cost [38,39].

Azadirachta indica, which is a common plant known as Neem, belongs to the Meliaceae family and is found abundantly in Malaysia. It is known for its various applications especially its medicinal property [40]. The phytochemicals present in Neem are namely terpenoids and flavanones, which act as reducing as well as capping agent and helping in stabilizing nanoparticles. Extensive literature surveyed on the plant revealed that the major constituent of the Azadirachta indica are nimbin [41], nimbidin [42,43], ninbidol [44,45], gedunin [46], sodium nimbinate [47,48], quercetin [46,49], salannin [50] and Azadirachtin [41].

The co-precipitation method of iron salts has been reported to be the simplest and most efficient chemical pathway to synthesis magnetite nanoparticles [1,2]. The nanoparticles are usually prepared by a mixture of ferrous and ferric salts with alkaline medium. Here, we report a one-pot reaction, facile, safe and eco-friendly co-precipitation approach that utilizing Azadiratcha Indica extract is a non-toxic and naturally available material along with sodium hydroxide $(\mathrm{NaOH})$ as the alkaline medium. The synthesized magnetite nanoparticles have been characterized by UV-VIS spectroscopy, Fourier transform infrared (FTIR), X-ray diffraction (XRD), transmission electron microscopy (TEM), field emission scanning electron microscope (FESEM) with energy dispersive X-ray spectrometer (EDX), and vibrating sample magnetometer (VSM).

\section{Results and Discussions}

\subsection{Fourier Transform Infrared (FTIR) Spectroscopy}

FTIR analysis was carried out to identify the presence of flavanones and terpenoids in the Azadirachta indica leaf extract which are accountable for the stabilization of iron oxide nanoparticles. The representative FTIR spectra of pure Azadirachta indica leaf extract and the synthesized $\mathrm{Fe}_{3} \mathrm{O}_{4}-\mathrm{NPs}$ are manifested in Figures 1 and 2. The strong stretching band appear around $3324 \mathrm{~cm}^{-1}$ (Figure 1) shows the presence of $\mathrm{N}-\mathrm{H}$ stretching and bending vibration of amine group $\mathrm{NH}_{2}$ and $\mathrm{OH}$ the overlapping of the stretching vibration of attributed for water and phenolic group of Azadirachta indica leaf extract molecules. After reduction, the decreases in intensity at $3433 \mathrm{~cm}^{-1}$ imply the involvement of phenolic group of Azadirachta indica in the reduction process.

The FTIR spectra exhibited an adsorption peak at $1633 \mathrm{~cm}^{-1}$ (Figure 1), which can be attributed to amide $\mathrm{C}=\mathrm{O}$ stretching indicating the presence of $-\mathrm{COOH}$ group in the Azadirachta indica leaf extract. The decreasing in intensity at $1680 \mathrm{~cm}^{-1}$ (Figure 2) signify the involvement of amide $\mathrm{C}=\mathrm{O}$ stretching in the reduction process. Meanwhile, the adsorption peak at $2428 \mathrm{~cm}^{-1}$ (Figure 2) corresponds to alkyne group present in phytoconstituents of extracts. Hence, the presence of these functional groups validates that flavanones or terpenoids molecules were chemically bonded to the surface of $\mathrm{Fe}_{3} \mathrm{O}_{4}-\mathrm{NPs}$. 
It is evident from the small shifts in the peak position (Figure 2) that there is strong interaction between $\mathrm{Fe}_{3} \mathrm{O}_{4}$-NPs with the flavanones or terpenoids of Azadirachta indica leaf extract molecules.

The appearance of new peaks (Figure 2) at $541 \mathrm{~cm}^{-1}, 505 \mathrm{~cm}^{-1}, 497 \mathrm{~cm}^{-1}$ and $468 \mathrm{~cm}^{-1}$ clearly indicate the presence of $\mathrm{Fe}-\mathrm{O}$ stretching band of iron oxide nanoparticles [51,52]. This observation confirmed the formation of Azadirachta indica mediated $\mathrm{Fe}_{3} \mathrm{O}_{4}-\mathrm{NPs}$ in one-pot reaction. The FTIR data suggested that the reasonable mechanism of $\mathrm{Fe}_{3} \mathrm{O}_{4}$-NPs formation may be due to the reduction of iron ions that takes place together with the phenolic compounds in the Azadirachta indica leaf extract $[53,54]$.

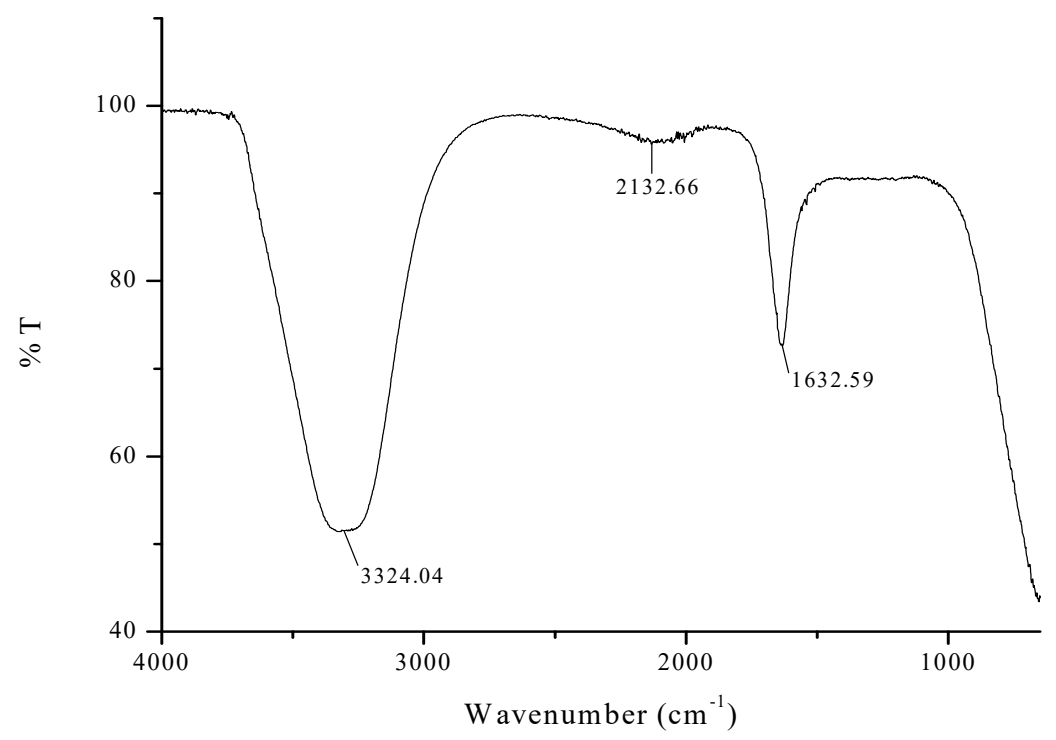

Figure 1. FTIR spectra of Neem leaf extract.

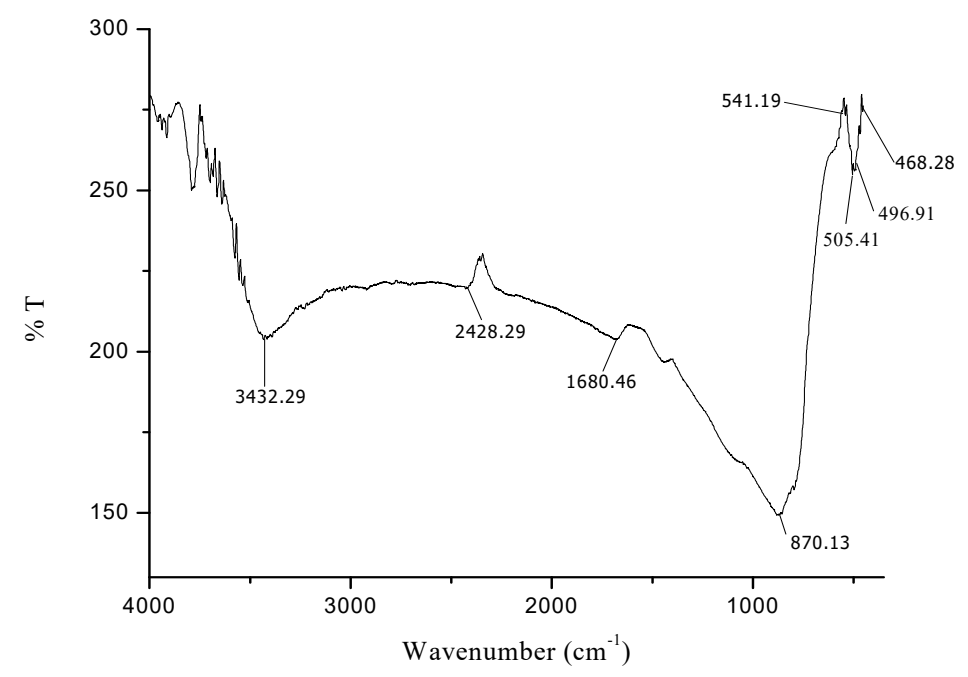

Figure 2. FTIR spectra of synthesized iron oxide nanoparticles.

\subsection{Ultraviolet-Visible (UV-VIS) Spectroscopy}

When aqueous Neem leaf extract was added to iron salts it resulted in a color change from pale yellow to light orange and finally to black color. The transformation of the color of the solution was due to the presence of iron oxide nanoparticles formed by the reduction of iron salts. It was suggested that compounds like terpenoids and flavanones act as reducing agent when Azadirachta indica leaf extract was used [55]. It was noticed that the instantaneous color change took after about $10 \mathrm{~min}$, thereafter no further color of the reaction mixture changed. This indicated that iron salts present in the reaction mixture had been reduced completely. Following this, the formation of $\mathrm{Fe}_{3} \mathrm{O}_{4}-\mathrm{NPs}$ was further confirmed by the UV-visible spectral analysis (Figure 3). The existence of a strong peak at 
around $242 \mathrm{~nm}$ regions was attributed to the excitation of surface plasmon vibrations in the iron oxide nanoparticles. This can be explained by the combined vibrations of free electrons of $\mathrm{Fe}_{3} \mathrm{O}_{4}-\mathrm{NPs}_{\mathrm{s}}$ in resonance with light wave. Works from Hassan et al. (2015) and Devatha et al. (2016) had reported identical UV-VIS spectra for synthesis $\mathrm{Fe}_{3} \mathrm{O}_{4}-\mathrm{NPs}[56,57]$. Thus, the $\mathrm{Fe}_{3} \mathrm{O}_{4}$-NPs can be synthesis within $10 \mathrm{~min}$ by this green method using non-toxic neem leaves make this synthesis method suitable for biomedical applications and biological studies.

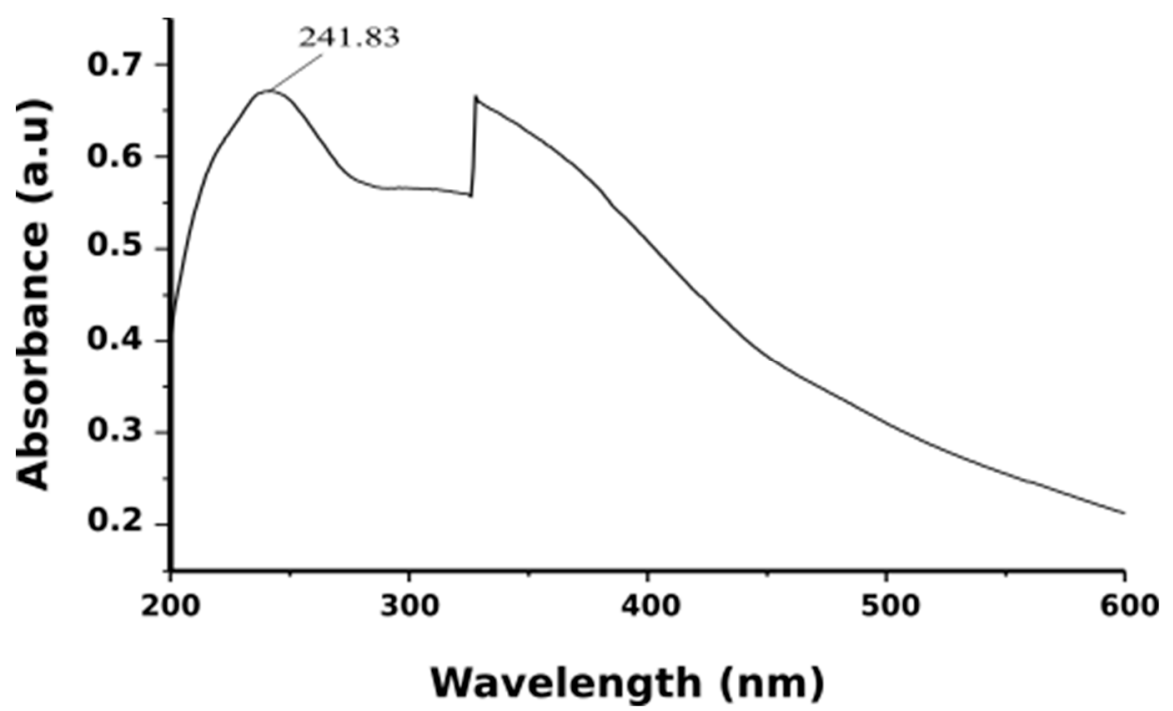

Figure 3. UV-visible absorption spectra of iron oxide nanoparticles.

\subsection{Transmission Electron Microscopy (TEM)}

TEM images recorded from drop coated grids of iron oxide nanoparticles are shown in Figure 4. Figure 4 shows that $\mathrm{Fe}_{3} \mathrm{O}_{4}-\mathrm{NPs}$ is found to be predominantly irregular in shape, and particle size ranging from $9 \mathrm{~nm}$ to $12 \mathrm{~nm}$ with some deviations. The obtained particle size coincidences with that calculated from Scherrer equation with average particle size of around $9.48 \mathrm{~nm}$. The good correlation between particles sizes obtained from the Scherrer equation and TEM supports the highly crystalline structure of the iron nanoparticles as shown by XRD. Yew et al. (2016) and Mahdavi et al. (2013) reported the similar results for $\mathrm{Fe}_{3} \mathrm{O}_{4}$-NPs [58,59].

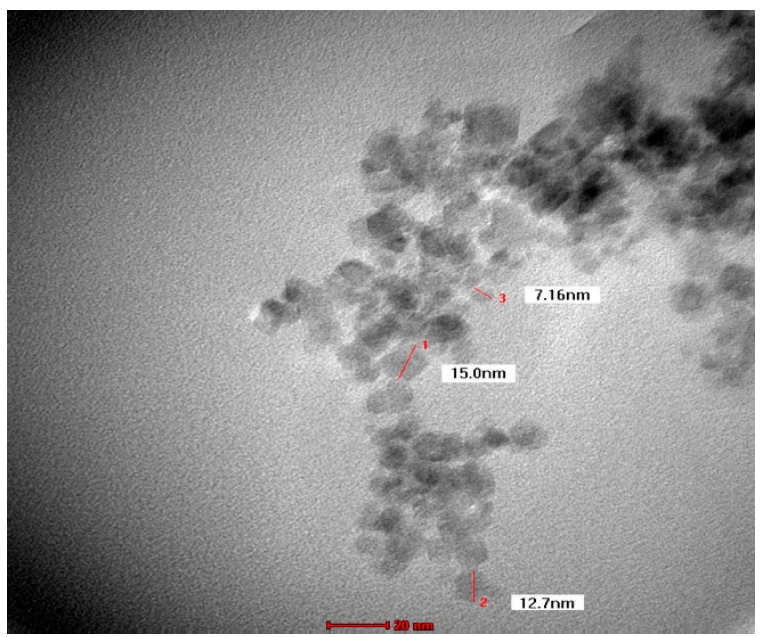

Figure 4. TEM micrograph of biosynthesized iron oxide nanoparticles. 


\subsection{Field Emission Electron Microscopy (FESEM) and Energy Dispersive X-ray (EDX)}

The surface morphology and elemental analysis of $\mathrm{Fe}_{3} \mathrm{O}_{4}$ nanoparticles were studied using FESEM coupled with EDX analysis. Figure 5 shows the FESEM image of the synthesized $\mathrm{Fe}_{3} \mathrm{O}_{4}$ nanoparticles consisted of nano-sized particles with a nearly spherical shape. It was observed that the nanoparticles formed were agglomerated with the particles and appear to adhere to each other, forming aggregate of particles, which result in irregular arrangements. The particles sizes measured about 9 to $12 \mathrm{~nm}$, hence supporting the TEM result.

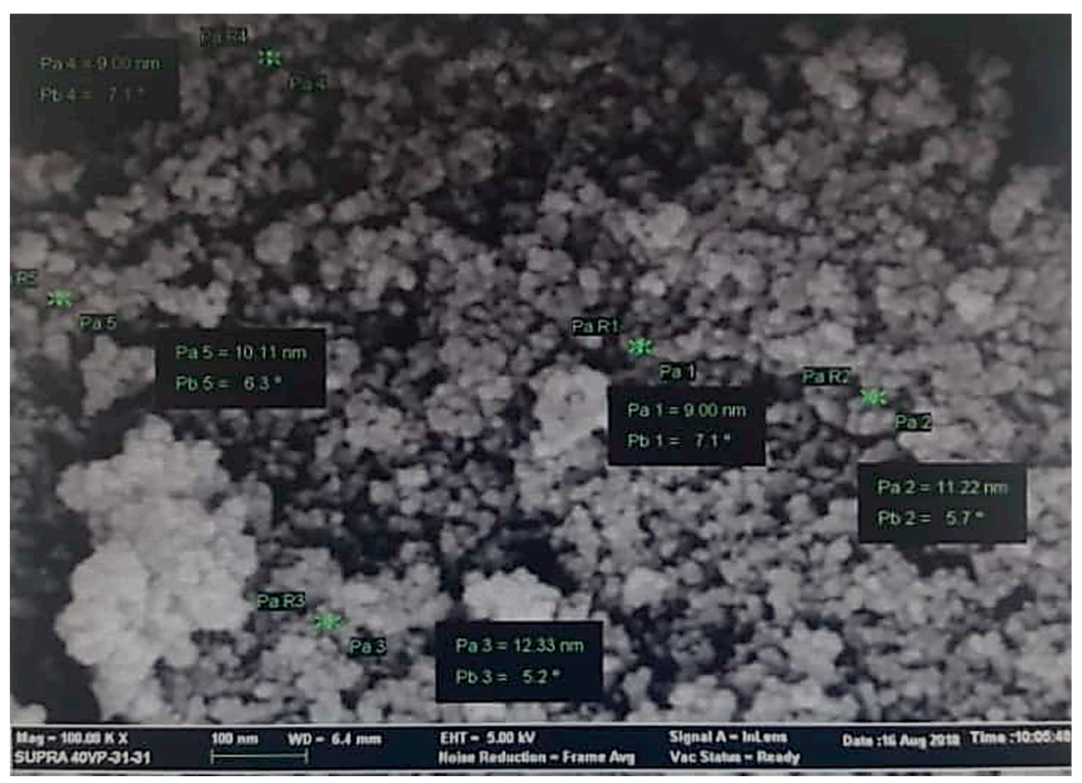

Figure 5. Field emission scanning electron microscopy (FESEM) micrograph of the biosynthesized iron oxide nanoparticles.

The presence of Fe (iron) and O (oxygen) with atomic percentage of $33.29 \%$ and $66.71 \%$ respectively was confirmed by EDX microanalysis (Figure 6). The presence of nanocrystalline elemental iron was confirmed by the distinctive peak, which was observed approximately at $0.6 \mathrm{keV}$. EDX spectra inferred the presence of elements Fe (iron) and $\mathrm{O}$ (oxygen) and thus confirmed the chemical composition of $\mathrm{Fe}_{3} \mathrm{O}_{4}$ nanoparticles.

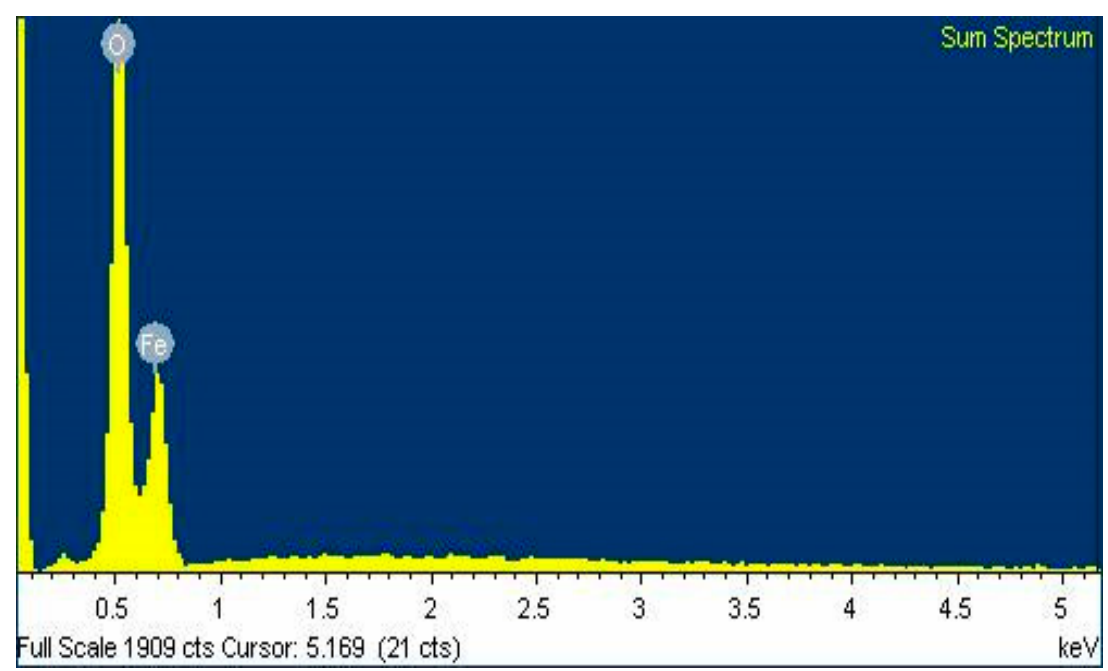

Figure 6. Energy dispersive X-ray spectroscopy (EDX) analysis spectra for $\mathrm{Fe}_{3} \mathrm{O}_{4}$ nanoparticles. 


\subsection{Powder X-Ray Diffraction (PXRD)}

The X-Ray powder diffraction measurement was performed at room temperature and a scan rate of $1^{\circ}$ per minute in $0.013^{\circ}$ steps, covering the $2 \theta$ angle from $15-80^{\circ}$. The XRD pattern of $\mathrm{Fe}_{3} \mathrm{O}_{4}$ showed that six characteristic diffraction peaks of $\mathrm{Fe}_{3} \mathrm{O}_{4}$ were observed at planes $2 \theta=(220)$ at $30.3^{\circ}(311)$ at $35.6^{\circ},(400)$ at $43.3^{\circ},(422)$ at $53.2^{\circ},(511)$ at $57.1^{\circ}$, and (440) at $62.8^{\circ}$. The room temperature of the XRD pattern of $\mathrm{Fe}_{3} \mathrm{O}_{4}$ was plotted by Rietveld refinement using GSAS and EXPGUI software [60,61]. Sample were indexed to a single phase cubic structure with $\mathrm{Fd} 3 \mathrm{~ms}$ space group and all the diffraction peaks were in good agreement with the JCPDS file No.19-0629 (JCPDS). Lattice parameters were determined using Rietveld refinement as $a=b=c=8.3559 \AA$ and the unit cell volume $=583.42 \AA^{3}$. A lattice parameter value of $8.356 \AA$ was reported for a similar synthesis of $\mathrm{Fe}_{3} \mathrm{O}_{4}$-NPs [62]. The observed lattice parameter was similar with that reported in the literature [63]. It was inferred that there were no other characteristic peaks detected in this pattern, indicating that purity of the synthesizes sample. Figure 7a and $b$ show the Rietveld refinement of the XRD and the structural of $\mathrm{Fe}_{3} \mathrm{O}_{4}$. Average crystalline size (D) was determined using the Debye-Scherrer [64] equation: $D=0.94 \lambda / \beta \cos \theta$, where $\lambda$ is the wavelength of $\mathrm{X}$-ray, $\beta$ is the broadening of the peak at half maximum. The average crystallite size was found to be $\sim 9.48 \mathrm{~nm}$. The intense and sharp peaks undoubtedly revealed that $\mathrm{Fe}_{3} \mathrm{O}_{4}-\mathrm{NPs}$ formed by the reduction of iron ions using Azadirachta indica aqueous extract were highly crystalline in nature.

(a)

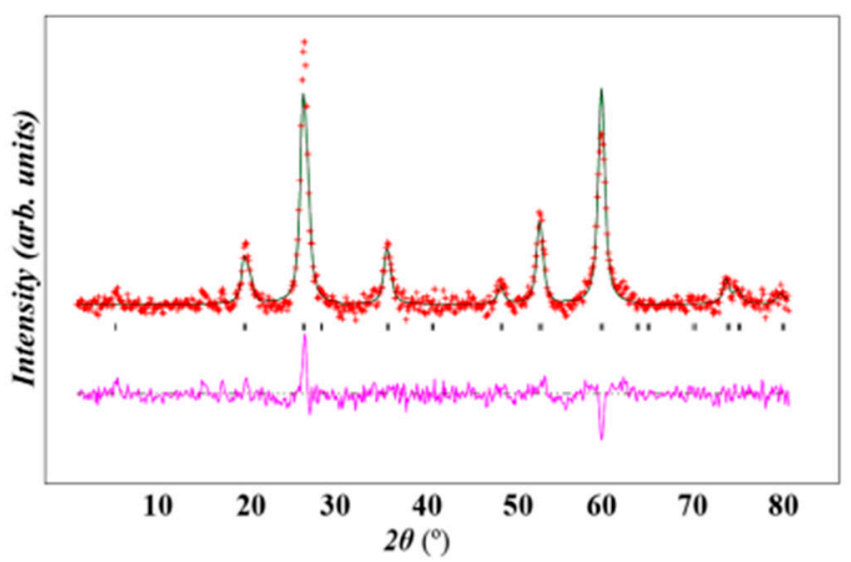

(b)

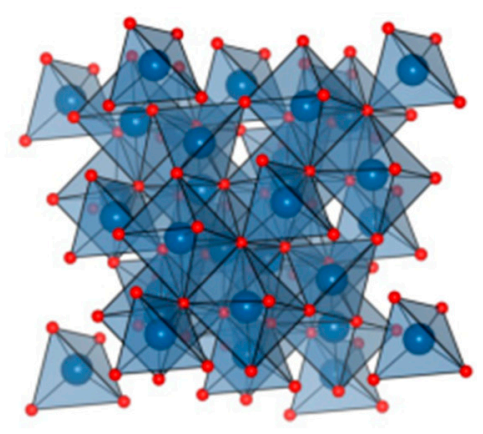

Figure 7. (a). XRD pattern with Rietveld refinement of $\mathrm{Fe}_{3} \mathrm{O}_{4}$. Crosses indicate the experimental data and the calculated profile is the black continuous line. The lowest curve shows the difference between experimental and calculated patterns. The black vertical bars indicate the expected reflection positions and (b) a polyhedral view of the $\mathrm{Fe}_{3} \mathrm{O}_{4}$ structure. Blue and red are occupied by $\mathrm{Fe}$ and $\mathrm{O}$ respectively.

\subsection{Magnetic Measurements}

Figure 8 shows the magnetization curves as a function of applied external magnetic field. No hysteresis and remanence appeared indicating the superparamagnetic materials in nature. The maximum saturation magnetization $(M s)$ of $\mathrm{Fe}_{3} \mathrm{O}_{4}$ composite was $73.040 \mathrm{emu} / \mathrm{g}$ of $\mathrm{Fe}_{3} \mathrm{O}_{4}$ and the coercive field (Hc) were equal to 4 Oe. Previous study by Anbarasu [65] and co-researchers showed that when the resultant particle size was decreasing, the saturation magnetization $\left(\mathrm{M}_{\mathrm{s}}\right)$ of magnetic nanoparticles (MNPs) was reduced. The reduced saturation magnetization of $\mathrm{Fe}_{3} \mathrm{O}_{4} \mathrm{NPs}$ compared with bulk magnetite $\left(92 \mathrm{emu} / \mathrm{g}\right.$ of $\left.\mathrm{Fe}_{3} \mathrm{O}_{4}\right)[63,66]$ is most likely due to the disordered spin layer at their surfaces [67]. Thus, when the size of the resultant particle size was decreasing, the ratio of disordered layer to the radius of the MNPs was significant. Surface spin disorder thus led to reduced Ms for smaller nanoparticles. Therefore, the way to enhance the $M s$ value was to increase the crystallize size of the magnetic particle. It has been reported that $M s$ of $7-22 \mathrm{emu} / \mathrm{g}$ is suitable for biomedical 
application [68,69]. Therefore, the level of $M s$ achieved for synthesized $\mathrm{Fe}_{3} \mathrm{O}_{4}$ nanoparticles is sufficient for biomedical applications.

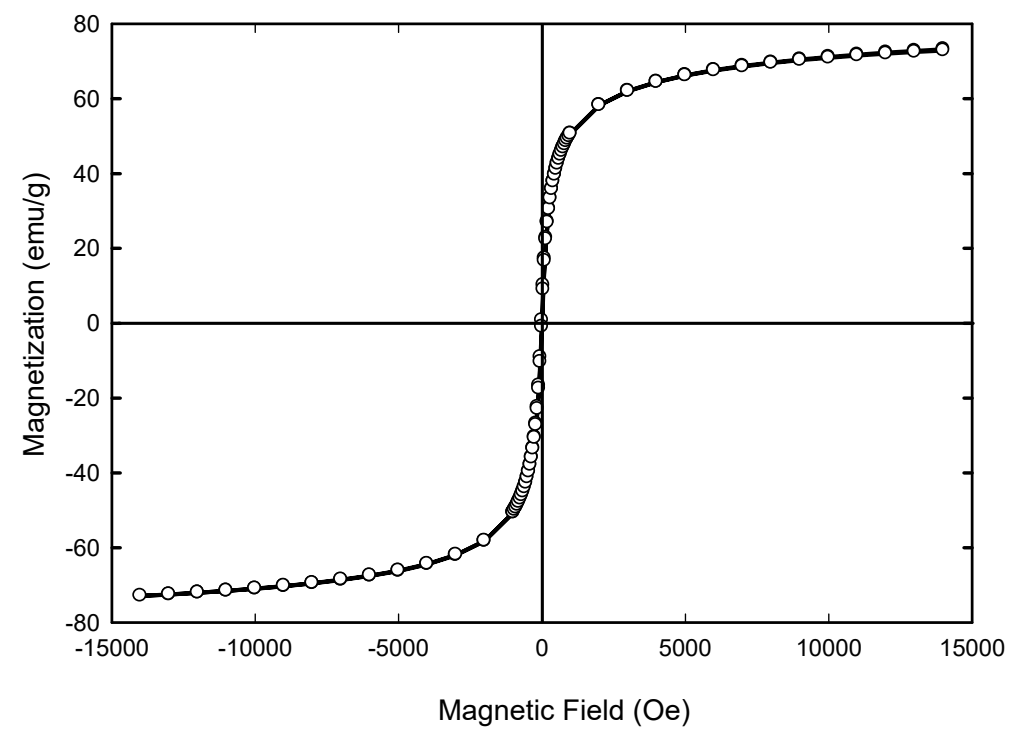

Figure 8. Magnetic hysteresis loop for the sample $\mathrm{Fe}_{3} \mathrm{O}_{4}$ at $300 \mathrm{~K}$.

\subsection{Magnetic Behaviour and Colloidal Stability of Iron Oxide Nanoparticles}

Figure 9 shows the behavior of $\mathrm{Fe}_{3} \mathrm{O}_{4}$ nanoparticles before and after the external magnetic field. They discreted easily in double distilled water and also could be drawn from the solution to the side wall of the vial by an external magnet. The black suspended aqueous solution turned transparent within seconds when it was placed nearby, suggesting that the obtained $\mathrm{Fe}_{3} \mathrm{O}_{4}$ nanoparticles have an excellent magnetic responsive. No phase separation was observed for one month which suggests that the magnetite nanoparticles have good dispersion properties.

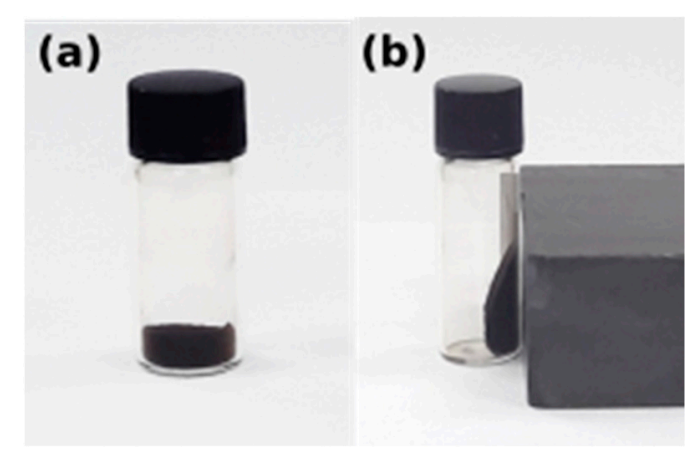

Figure 9. Iron oxide nanoparticles (a) without external magnetic field and (b) under external magnetic field.

\section{Materials and Methods}

\subsection{Materials}

Iron (II) chloride tetrahydrate $\left(\mathrm{FeCl}_{2} \cdot 4 \mathrm{H}_{2} \mathrm{O}\right)$ and iron (III) chloride hexahydrate $\left(\mathrm{FeCl}_{3} \cdot 6 \mathrm{H}_{2} \mathrm{O}\right)$ were all purchased from Sigma Aldrich, St. Louis, MO, USA. NaOH pellets were obtained from MERCK KGaA (Darmstadt, Germany). All chemicals were of analytical grade and utilized without further purification. 


\subsection{Preparation of Azadirachta Indica (Neem Leaves) Extract}

In this work, the healthy leaves of Azadirachta indica (neem leaves) were collected from Batu Caves, Selangor, Malaysia. The collected leaves were thoroughly washed several times with distilled water to remove dust particle and then air dried at room temperature to remove the remaining moisture. Then, the dried leaves were cut into small pieces and crushed into fine powder. Approximately, $5 \mathrm{~g}$ of finely grinded neem leaf powder was mixed with $100 \mathrm{~mL}$ sterile distilled water in a conical flask and the mixture was heated with boiling at constant temperature of $80^{\circ} \mathrm{C}$. Then, the mixture was left to cool at room temperature before vacuum-filtered through Whatman filter paper No. 1 to obtain plant extract. The green clear filtered solution of extract was stored at $4{ }^{\circ} \mathrm{C}$ for further use.

\subsection{Biosynthesis of Iron Oxide $\left(\mathrm{Fe}_{3} \mathrm{O}_{4}\right)$ Nanoparticles}

Iron oxide nanoparticles were synthesized following a simple one-pot-two-step co-precipitation approach using Azadirachta indica (neem leaves) extract as the green reducing agent. In a typical procedure, $0.40 \mathrm{~g}$ iron (II) chloride tetrahydrate $\left(\mathrm{FeCl}_{2} \cdot 4 \mathrm{H}_{2} \mathrm{O}\right)$ and $1.10 \mathrm{~g}$ of iron (III) chloride hexahydrate $\left(\mathrm{FeCl}_{3} \cdot 6 \mathrm{H}_{2} \mathrm{O}\right)$ with 1:2 molar ratios were dissolved in $100 \mathrm{~mL}$ of sterile deionized water under nitrogen blanket. Following this, the resulting mixture was heated up to $80^{\circ} \mathrm{C}$ under mild stirring for $10 \mathrm{~min}$ in oil bath to obtain homogeneous solution. Then, $5 \mathrm{~mL}$ of aqueous neem leaf extract was added slowly into the hot resulting mixture and subsequently $20 \mathrm{~mL}$ of sodium hydroxide $(\mathrm{NaOH})$ was added into the reaction mixture drop by drop using burette under vigorous stirring for $30 \mathrm{~min}$. The instantaneous black color appearance indicated the formation of $\mathrm{Fe}_{3} \mathrm{O}_{4}-\mathrm{NPs}$. The resulting mixture was allowed to cool at room temperature. After $30 \mathrm{~min}$, the solution was poured into a beaker and magnetic decantation was carried out in order to remove the supernatant. The intense black precipitate $\mathrm{Fe}_{3} \mathrm{O}_{4}-\mathrm{NPs}$ was then washed with $15 \mathrm{~mL}$ deionized water and centrifuged at $5000 \mathrm{rpm}$ for $10 \mathrm{~min}$ in order to remove any residual salts. The supernatant was removed. The product was washed again with $10 \mathrm{~mL}$ of deionized water followed by centrifugation. The supernatant was removed again. The pellet was transferred to a vial and $10 \mathrm{~mL}$ deionized water was added. The obtained black powder was proceeded to freeze drying overnight and used for further characterizations.

\subsection{Characterization}

UV-visible spectral analysis was measured in aqueous solution by using Perkin Elmer UV-VIS spectrometer Lambda 35 (Perkin Elmer, Waltham, MA, USA) with a resolution of $1 \mathrm{~nm}$ between 200 and $600 \mathrm{~nm}$ to confirm the formation of $\mathrm{Fe}_{3} \mathrm{O}_{4}$ nanoparticles. The size and the morphology of the $\mathrm{Fe}_{3} \mathrm{O}_{4}$-NPs was investigated by means of a transmission electron microscopy (TEM) using Technai G2 $20 S$ Twin TEM, Eindhoven, Netherlands working at $200 \mathrm{kV}$. The samples were prepared by drop deposition of a diluted solution onto a carbon-coated copper grid. The grid was air-dried for a few hours prior to the TEM studies. X-ray powder diffraction (XRD) was used to analyze the structure and identify the phase purity of $\mathrm{Fe}_{3} \mathrm{O}_{4}$ compounds. The samples were placed on a flat plate while intensity data were collected as a function of the Bragg angle, $\theta$, in the range $2 \theta=15^{\circ}$ to $80^{\circ}$ with a step size of $0.013^{\circ}$ using a PANanalytical X'pert PRO diffractometer in Bragg-Brentono geometry using $\mathrm{Cu} \mathrm{K} \mathrm{K}_{\alpha}$ radiation wavelength $\lambda_{\alpha 1}=1.5405 \AA, \lambda_{\alpha 2}=1.5443 \AA$. The structures were refined with the full-profile Rietveld method using GSAS [60] with the EXPGUI interface [61]. Fourier transform infrared (FTIR) spectra were collected using a Perkin Elmer Spectrum One FTIR spectrophotometer (Perkin Elmer) using the $\mathrm{KBr}$ pellet method with a range of $4000-400 \mathrm{~cm}^{-1}$. The surface morphology and atomic ratio of the $\mathrm{Fe}_{3} \mathrm{O}_{4}$-NPs was determined by using FESEM-EDX (ZEISS supra 40VP, Oberkochen, Germany). The magnetic properties of the prepared $\mathrm{Fe}_{3} \mathrm{O}_{4}$ was revealed using a vibrating sample magnetometer (VSM, Lake Shore 7404, McCorkle Boulevard, Westerville, OH, USA) at room temperature $300 \mathrm{~K}$. The magnetization measurements, $M_{s}$ as a function of applied field $(H)$ were measured under external magnetic fields up to $\pm 14,000$ Oe. 


\section{Conclusions}

In this present study, we reported the successful use of Azadirachta indica as a one-pot green method for the synthesis of iron oxide nanoparticles. The color change, observed instantaneously suggested that the formation of black colored solution indicated the formation of iron oxide nanoparticles. The rapid reduction process proved the efficiency of Azadirachta indica extract as reducing and stabilizing agents. The XRD pattern showed the cubic crystal structure of iron oxide nanoparticles without any impurities. FTIR showed that the interactions that existed between Azadirachta indica and iron oxide nanoparticles. TEM showed the formation of $\mathrm{Fe}_{3} \mathrm{O}_{4}$ with an average size of 9-12 nm with irregular shape. Overall, the proposed green synthetic method was simple and eco-friendly, because it did not require any extra surfactants or reductants. Achievement of such rapid time scales for synthesis of iron oxide nanoparticles could be a competitive alternative to the conventional chemical protocols and a low cost candidate as reductant for synthesis of iron oxide nanoparticles, and thus, it has the potential to use in biomedical applications and will play an important role in magnetic targeting drug delivery in near future. From these studies, it can be inferred that $\mathrm{Fe}_{3} \mathrm{O}_{4}-\mathrm{NPs}$ biosynthesis may possibly be a gateway to our various health concerns.

Author Contributions: N.D.S.Z. performed experiments, analyzed data and wrote the paper; F.A.L. supervised experiments, analyzed data and wrote the paper; Z.M. analyzed data and wrote the paper; N.I.T. designed, supervised experiments, analyzed data, wrote and edit the paper.

Funding: The authors would like to acknowledge the financial support by Ministry of Higher Education (MOHE), Malaysia and Universiti Teknologi Mara (UiTM), Malaysia for financial support through the Fundamental Research Grant Scheme (600-IRMI/FRGS 5/3 (046/2017)).

Acknowledgments: The authors are grateful to the Faculty of Applied Sciences, Unversiti Teknologi (MARA) for laboratory facilities. The microscopy analysis was carried out using facilities at the Microscopy and Microanalysis Facility at the Faculty of Pharmacy, Universiti Teknologi MARA (UiTM), Puncak Alam Campus. Meanwhile, VSM was performed at Universiti Kebangsaan Malaysia.

Conflicts of Interest: The authors declare no conflicts of interest.

\section{References}

1. Chin, S.F.; Pang, S.C.; Tan, C.H. Green synthesis of magnetite nanoparticles (via thermal decomposition method) with controllable size and shape. J. Mater. Environ. Sci. 2011, 2, 299-302.

2. Laurent, S.; Forge, D.; Port, M.; Roch, A.; Robic, C.; Vander Elst, L.; Muller, R.N. Magnetic iron oxide nanoparticles: synthesis, stabilization, vectorization, physicochemical characterizations, and biological applications. Chem. Rev. 2008, 108, 2064-2110. [CrossRef] [PubMed]

3. Mahmoudi, M.; Sant, S.; Wang, B.; Laurent, S.; Sen, T. Superparamagnetic iron oxide nanoparticles (SPIONs): development, surface modification and applications in chemotherapy. Adv. Drug. Deliv. Rev. 2011, 63, $24-46$. [CrossRef] [PubMed]

4. Qiao, R.; Yang, C.; Gao, M. Superparamagnetic iron oxide nanoparticles: from preparations to in vivo MRI applications. J. Mater. Chem. 2009, 19, 6274-6293. [CrossRef]

5. Pankhurst, Q.A.; Connolly, J.; Jones, S.K.; Dobson, J. Applications of magnetic nanoparticles in biomedicine. J. Phys. D Appl. Phys. 2003, 36, R167-R181. [CrossRef]

6. Sangaiya, P.; Jayaprakash, R. A Review on Iron Oxide Nanoparticles and Their Biomedical Applications. J. Supercond. Novel Magn. 2018, 31, 3397-3413. [CrossRef]

7. El-Boubbou, K. Magnetic iron oxide nanoparticles as drug carriers: Preparation, conjugation and delivery. Nanomedicine 2018, 13, 929-952. [CrossRef]

8. Guerrero-Martinez, A.; Perez-Juste, J.; Liz-Marzan, L.M. Recent progress on silica coating of nanoparticles and related nanomaterials. Adv. Mater. 2010, 22, 1182-1195. [CrossRef]

9. Nel, A.; Xia, T.; Mädler, L.; Li, N. Toxic potential of materials at the nanolevel. Science 2006, 311, 622-627. [CrossRef]

10. Kim, J.; Grate, J.W.; Wang, P. Nanostructures for enzyme stabilization. Chem. Eng. Sci. 2006, 61, 1017-1026. [CrossRef] 
11. Wan, Y.; Zhao, D. On the controllable soft-templating approach to mesoporous silicates. Chem. Rev. 2007, 107, 2821-2860. [CrossRef] [PubMed]

12. Cui, J.; Ren, S.; Lin, T.; Feng, Y.; Jia, S. Shielding effects of $\mathrm{Fe}^{3+}$-tannic acid nanocoatings for immobilized enzyme on magnetic $\mathrm{Fe}_{3} \mathrm{O} 4 @$ @ilica core shell nanosphere. Chem. Eng. J. 2018, 343, 629-637. [CrossRef]

13. Li, L.; Lu, Y.; Jiang, C.; Zhu, Y.; Yang, X.; Hu, X.; Lin, Z.; Zhang, Y.; Peng, M.; Xia, H.; et al. Cancer Nanotheranostics: Actively Targeted Deep Tissue Imaging and Photothermal-Chemo Therapy of Breast Cancer by Antibody-Functionalized Drug-Loaded X-Ray-Responsive Bismuth Sulfide@Mesoporous Silica Core-Shell Nanoparticles (Adv. Funct. Mater. 5/2018). Adv. Funct. Mater. 2018, 28, 1870034. [CrossRef]

14. Beg, M.S.; Mohapatra, J.; Pradhan, L.; Patkar, D.; Bahadur, D. Porous Fe3O4-SiO2 core-shell nanorods as high-performance MRI contrast agent and drug delivery vehicle. J. Magn. Magn. Mater. 2017, 428, 340-347. [CrossRef]

15. Neuberger, T.; Schopf, B.; Hofmann, H.; Hofmann, M.; von Rechenberg, B. Superparamagnetic nanoparticles for biomedical applications: Possibilities and limitations of a new drug delivery system. J. Magn. Magn. Mater. 2005, 293, 483-496. [CrossRef]

16. Wang, B.; Wei, Q.; Qu, S. Synthesis and characterization of uniform and crystalline magnetite nanoparticles via oxidation-precipitation and modified co-precipitation methods. Int. J. Electrochem. Sci. 2013, 8, 3786-3793.

17. Malik, M.A.; YounusWani, M.; Hashim, M.A. Microemulsion method: a novel route to synthesize organic and inorganic nanomaterials. Arab. J. Chem. 2012, 5, 397-417. [CrossRef]

18. Izquierdo, P.; Esquena, J.; Tadros, T.F.; Dederen, J.C.; Feng, J.; Garcia-Celma, M.J.; Azemar, N.; Solans, C. Phase behavior and nano-emulsion formation by the phase inversion temperature method. Langmuir 2004, 20, 6594-6598. [CrossRef]

19. Wannoussa, W.; Masy, T.; Lambert, S.D.; Heinrichs, B.; Tasseroul, L.; Al-Ahmad, A.; Weekers, F.; Thonart, P.; Hiligsmann, S. Effect of iron nanoparticles synthesized by a sol-gel process on rhodococcus erythropolis T902.1 for biphenyl degradation. J. Water Res. Protect. 2015, 7, 264-277. [CrossRef]

20. Zhuang, L.; Zhang, W.; Zhao, Y.; Shen, H.; Lin, H.; Liang, J. Preparation and characterization of Fe3O4 particles with novel nanosheets morphology and magnetochromatic property by a modified solvothermal method. Sci. Rep. 2015, 5, 9320. [CrossRef]

21. Liu, X.; Peng, M.L.; Li, G.; Miao, Y.Q.; Luo, H.; Jing, G.; He, Y.; Zhang, C.; Zhang, F.; Fan, H. Ultrasonication-Triggered Ubiquitous Assembly of Magnetic Janus Amphiphilic Nanoparticles in Cancer Theranostic Applications. Nano Lett. 2019, 19, 4118-4125. [CrossRef] [PubMed]

22. Park, J.; An, K.; Hwang, Y.; Park, J.G.; Noh, H.J.; Kim, J.Y.; Park, J.H.; Hwang, N.M.; Hyeon, T. Ultra-large-scale syntheses of monodisperse nanocrystals. Nat. Mater. 2004, 3, 891. [CrossRef] [PubMed]

23. Sun, S.; Zeng, H. Size-controlled synthesis of magnetite nanoparticles. J. Am. Chem. Soc. 2002, 124, 8204-8205. [CrossRef] [PubMed]

24. Zhang, H.; Li, L.; Liu, X.L.; Jiao, J.; Ng, C.T.; Yi, J.B.; Luo, Y.E.; Bay, B.-H.; Zhao, L.Y.; Peng, M.L.; et al. Ultrasmall ferrite nanoparticles synthesized via dynamic simultaneous thermal decomposition for high-performance and multifunctional T 1 magnetic resonance imaging contrast agent. ACS Nano 2017, 11, 3614-3631. [CrossRef] [PubMed]

25. Hasany, S.F.; Ahmed, I.; Rajan, J.; Rehman, A. Systematic review of the preparation techniques of iron oxide magnetic nanoparticles. Nanosci. Nanotech. 2012, 2, 148-158. [CrossRef]

26. Thakkar, K.N.; Mhatre, S.S.; Parikh, R.Y. Biological synthesis of metallic nanoparticles. Nanomed. Nanotech. Biol. Med. 2010, 6, 257-262. [CrossRef]

27. Song, H.; Carraway, E.R. Reduction of chlorinated ethanes by nanosized zero-valent iron: kinetics, pathways, and effects of reaction conditions. Environ. Sci. Tech. 2005, 39, 6237-6245. [CrossRef]

28. Kim, J.H.; Tratnyek, P.G.; Chang, Y.S. Rapid dechlorination of polychlorinated dibenzo-p-dioxins by bimetallic and nano- sized zerovalent iron. Environ. Sci. Tech. 2008, 2, 4106-4112. [CrossRef]

29. Khatami, M.; Alijani, H.Q.; Nejad, M.S.; Varma, R.S. Core@ shell nanoparticles: greener synthesis using natural plant products. Appl. Sci. 2018, 8, 411. [CrossRef]

30. Senapati, S.; Ahmad, A.; Khan, M.I.; Sastry, M.; Kumar, R. Extracellular biosynthesis of bimetallic Au-Ag alloy nanoparticles. Small 2005, 1,517-520. [CrossRef]

31. Klaus, T.; Joerger, R.; Olsson, E.; Granqvist, C.-G.R. Silver-based crystalline nanoparticles, microbially fabricated. Proc. Natl. Acad. Sci. USA 1999, 96, 13611-13614. [CrossRef] [PubMed] 
32. Bansal, V.; Rautaray, D.; Ahmad, A.; Sastry, M. Biosynthesis of zirconia nanoparticles using the fungus Fusarium oxysporum. J. Mater. Chem. 2004, 14, 3303-3305. [CrossRef]

33. Mohanpuria, P.; Rana, N.K.; Yadav, S.K. Biosynthesis of nanoparticles: technological concepts and future applications. J. Nanoparticle Res. 2008, 10, 507-517. [CrossRef]

34. Rai, M.; Yadav, A.; Gade, A. CRC 675-current trends in phytosynthesis of metal nanoparticles. Critic. Rev. Biotechnol. 2008, 28, 277-284. [CrossRef] [PubMed]

35. Saif, S.; Tahir, A.; Chen, Y. Green Synthesis of Iron Nanoparticles and Their Environmental Applications and Implications. Nanomaterials 2016, 6, 209. [CrossRef] [PubMed]

36. Herlekar, M.; Barve, S.; Kumar, R. Plant-mediated green synthesis of iron nanoparticles. J. Nanoparticles 2014, 2014, 1-9. [CrossRef]

37. Naseem, T.; Farrukh, M.A. Antibacterial activity of green synthesis of iron nanoparticles using Lawsonia inermis and Gardenia jasminoides leaves extract. J. Chem. 2015, 2015, 1-9. [CrossRef]

38. Shankar, S.S.; Rai, A.; Ahmad, A.; Sastry, M. Rapid synthesis of Au, Ag, and bimetallic Au core-Ag shell nanoparticles using Neem (Azadirachta indica) leaf broth. J. Colloid Interface Sci. 2004, 275, 4960502. [CrossRef]

39. Sathishkumar, M.; Sneha, K.; Yun, Y.-S. Immobilization of silver nanoparticles synthesized using Curcuma longa tuber powder and extract on cotton cloth for bactericidal activity. Bioresour.Technol. 2010, 101, 7958-7965. [CrossRef]

40. Biswas, K.; Chattopadhya, I.; Banerjee, R.K.; Bandyopadhyay, U. Biological activities and medicinal properties of neem (Azadirachta indica). Curr. Sci.-Bangalore 2002, 82, 1336-1345.

41. Saleem, S.; Muhammad, G.; Hussain, M.A.; Bukhari, S.N.A. A comprehensive review of phytochemical profile, bioactive for pharmaceuticals and pharmacological attributes of Azadirachta indica. Phytother. Res. 2018, 32, 1241-1272. [CrossRef] [PubMed]

42. Linton, Y.M.; Nisbet, A.J.; Mordue, A.J. The effects of azadirachtin on the testes of the desert locust, Schistocerca gregaria (Forskål). J. Insect Physiol. 1997, 43, 1077-1084. [CrossRef]

43. Luntz, A.J.M.; Nisbet, A.J.; Nasiruddin, M.; Walker, E. Differential thresholds of azadirachtin for feeding deterrence and toxicity in locusts and an aphid. In Proceedings of the 9th International Symposium on Insect-Plant Relationships; Springer: Dordrecht, The Netherland, 1996; pp. 69-72.

44. Jiang, Z.-H.; Yang, Q.-X.; Tanaka, T.; Kouno, I. Bicyclic polyketide lactones from Chinese medicinal ants, Polyrhacis lamellidens. J. Nat. Product. 2008, 71, 724-727. [CrossRef]

45. Simmonds, M.S.J.; Manlov, J.D.; Blaney, W.M.; Khambay, B.P.S. Effect of Botanical Insecticides on the Foraging and Feeding Behavior of the Coccinellid PredatorCryptolaemus montrouzieri. Phytoparasitica 2000, 28, 99. [CrossRef]

46. Chutulo, E.C.; Chalannavar, R.K. Endophytic mycoflora and their bioactive compounds from Azadirachta indica: A comprehensive review. J. Fungi 2018, 4, 42. [CrossRef]

47. Benelli, G.; Caselli, A.; Giuseppe, G.D.; Canale, A. Control of biting lice, Mallophaga- a review. Acta Tropica 2018, 177, 211-219. [CrossRef]

48. Nisbet, A.J.; Woodford, J.A.T.; Strang, R.H.C. The effects of azadirachtin-treated diets on the feeding behaviour and fecundity of the peach-potato aphid, Myzus persicae. Entomol. Exp. Appl. 1994, 71, 65-72. [CrossRef]

49. Gupta, S.C.; Prasad, S.; Tyagi, A.K.; Kunnumakkara, A.B.; Aggarwal, B.B. Neem (Azadirachta indica): An indian traditional panacea with modern molecular basis. Phytomedicine 2017, 34, 14-20. [CrossRef]

50. Nisbet, A.J.; Mordue, A.J.; Grossman, R.B.; Jennens, L.; Ley, S.V.; Mordue, W. Characterization of azadirachtin binding to Sf9 nuclei in vitro. Arch. Insect. Biochem. Physiol. 2001, 46, 78-86. [CrossRef]

51. Demir, A.; Topkaya, R.; Baykal, A. Green synthesis of superparamagnetic Fe3O4 nanoparticles with maltose: Its magnetic investigation. Polyhedron 2013, 65. [CrossRef]

52. Yuvakkumar, R.; Hong, S.I. Green synthesis of spinel magnetite iron oxide nanoparticles. Adv.Mater. Res. 2014, 1051, 39-42. [CrossRef]

53. Prasad, C.; Gangadhara, S.; Venkateswarlu, P. Bio-inspired green synthesis of Fe3O4 magnetic nanoparticles using watermelon rinds and their catalytic activity. Appl. Nanosci. 2016, 6, 797-802. [CrossRef]

54. Abdullah, N.I.S.B.; Ahmad, M.B.; Shameli, K. Biosynthesis of silver nanoparticles using Artocarpus elasticus stem bark extract. Chem. Central J. 2015, 9, 61. [CrossRef] [PubMed]

55. Verma, A.; Mehata, M.S. Controllable synthesis of silver nanoparticles using Neem leaves and their antimicrobial activity. J. Radiat. Res. Appl. Sci. 2016, 9, 109-115. [CrossRef] 
56. Devatha, C.P.; Thalla, A.K.; Katte, S.Y. Green synthesis of iron nanoparticles using different leaf extracts for treatment of domestic waste water. J. Clean. Prod. 2016, 139, 1425-1435. [CrossRef]

57. Asoufi, H.M.; Al-Antary, T.M.; Awwad, A.M. Magnetite (Fe3O4) Nanoparticles Synthesis and Anti Green Peach Aphid Activity (Myzuspersicae Sulzer). J. Chem. Biochem. 2018, 6, 9-16. [CrossRef]

58. Mahdavi, M.; Namvar, F.; Ahmad, M.B.; Mohamad, R. Characterization of Magnetic Iron Oxide (Fe3O4) Nanoparticles Using Seaweed (Sargassum muticum) Aqueous Extract. Molecules 2013, 18, 5954-5964. [CrossRef]

59. Yew, Y.P.; Shameli, K.; Miyake, M.; Kuwano, N.; Khairudin, N.B.B.A.; Mohamad, S.E.B.; Lee, K.X. Green Synthesis of Magnetite (Fe3O4) Nanoparticles Using Seaweed (Kappaphycus alvarezii) Extract. Nanoscale Res. Lett. 2016, 11. [CrossRef]

60. Larson, A.C.; Dreele, R.B.V. General structure analysis system (GSAS) (Report LAUR 86-748); Los Alamos National Laboratory: Los Alamos, NM, USA, 1994; pp. 86-748.

61. Toby, B.H. EXPGUI, a graphical user interface for GSAS. J. Appl. Crystallogr. 2001, 34, 210-213. [CrossRef]

62. Venkateswarlu, S.; Kumar, B.N.; Prasad, C.H.; Venkateswarlu, P.; Jyothi, N.V.V. Bio-inspired green synthesis of Fe3O4 spherical magnetic nanoparticles using Syzygium cumini seed extract. Phys. B Condens. Matter. 2014, 449, 67-71. [CrossRef]

63. Zaitsev, V.S.; Filimonov, D.S.; Presnyakov, I.A.; Gambino, R.J.; Chu, B. Physical and Chemical Properties of Magnetite and Magnetite-Polymer Nanoparticles and Their Colloidal Dispersions. J. Colloid Interface Sci. 1999, 212, 49-57. [CrossRef] [PubMed]

64. Cullity, B.D.; Stock, S.R. Elements of X-ray Diffraction, 3rd ed.; Prentice Hall: Upper Saddle River, NJ, USA, 2001.

65. Anbarasu, M.; Anandan, M.; Chinnasamy, E.; Gopinath, V.; Balamurugan, K. Synthesis and characterization of polyethylene glycol (PEG) coated Fe3O4 nanoparticles by chemical co-precipitation method for biomedical applications. Spectrochim. Acta Part A Mol. Biomol. Spectrosc. 2015, 135, 536-539. [CrossRef] [PubMed]

66. Lee, Y.; Lee, J.; Bae, C.J.; Park, J.G.; Noh, H.J.; Park, J.H.; Hyeon, T. Large-Scale Synthesis of Uniform and Crystalline Magnetite Nanoparticles Using Reverse Micelles as Nanoreactors under Reflux Conditions. Adv. Funct. Mater. 2005, 15, 503-509. [CrossRef]

67. Petcharoen, K.; Sirivat, A. Synthesis and characterization of magnetite nanoparticles via the chemical co-precipitation method. Mater. Sci. Eng. B 2012, 177, 421-427. [CrossRef]

68. Brusentsov, N.A.; Gogosov, V.V.; Brusentsova, T.N.; Sergeev, A.V.; Jurchenko, N.Y.; Kuznetsov, A.A.; Kuznetsov, O.A.; Shumakov, L.I. Evaluation of ferromagnetic fluids and suspensions for the site-specific radiofrequency-induced hyperthermia of MX11 sarcoma cells in vitro. J. Magn. Magn. Mater. 2001, 225, 113-117. [CrossRef]

69. Xu, C.; Xu, K.; Gu, H.; Zhong, X.; Guo, Z.; Zheng, R.; Zhang, X.; Xu, B. Nitrilotriacetic acid-modified magnetic nanoparticles as a general agent to bind histidine-tagged proteins. J. Am. Chem. Soc. 2004, 126, 3392-3393. [CrossRef] [PubMed]

Sample Availability: Samples of the neem iron oxide nanoparticles are available from the authors.

(C) 2019 by the authors. Licensee MDPI, Basel, Switzerland. This article is an open access article distributed under the terms and conditions of the Creative Commons Attribution (CC BY) license (http://creativecommons.org/licenses/by/4.0/). 